\title{
Disrupted Sleep: From Molecules to Cognition
}

\author{
Eus J.W. Van Someren, ${ }^{1,2} \oplus^{\circledR C}$ Chiara Cirelli, ${ }^{3}$ Derk-Jan Dijk, ${ }^{4}$ Eve Van Cauter, ${ }^{5}$ Sophie Schwartz, ${ }^{6}$ and ${ }^{\oplus}$ Michael W.L. Chee ${ }^{7}$ \\ ${ }^{1}$ Department of Sleep and Cognition, Netherlands Institute for Neuroscience, an institute of the Royal Netherlands Academy of Arts and Sciences, 1105 BA, \\ Amsterdam, The Netherlands, ${ }^{2}$ Departments of Integrative Neurophysiology and Medical Psychology, Center for Neurogenomics and Cognitive Research, \\ Neuroscience Campus Amsterdam, VU University and Medical Center, 1081 HV, Amsterdam, The Netherlands, ${ }^{3}$ Department of Psychiatry, University of \\ Wisconsin-Madison, Madison, Wisconsin 53719, ${ }^{4}$ Surrey Sleep Research Centre, Faculty of Health and Medical Sciences, University of Surrey, Guildford \\ GU2 7XP, United Kingdom, ${ }^{5}$ Sleep, Metabolism and Health Center, Department of Medicine, University of Chicago, Illinois 60637, ${ }^{6}$ Department of \\ Neuroscience and Swiss Center for Affective Sciences, University of Geneva, Switzerland CH-1211, and ${ }^{7}$ Centre for Cognitive Neuroscience, Duke-NUS \\ Medical School, Singapore 169857
}

Although the functions of sleep remain to be fully elucidated, it is clear that there are far-reaching effects of its disruption, whether by curtailment for a single night, by a few hours each night over a long period, or by disruption in sleep continuity. Epidemiological and experimental studies of these different forms of sleep disruption show deranged physiology from subcellular levels to complex affective behavior. In keeping with the multifaceted influence of sleep on health and well-being, we illustrate how the duration of sleep, its timing, and continuity can affect cellular ultrastructure, gene expression, metabolic and hormone regulation, mood, and vigilance. Recent brain imaging studies provide some clues on mechanisms underlying the most common cause of disrupted sleep (insomnia). These insights should ultimately result in adequate interventions to prevent and treat sleep disruption because of their high relevance to our most prevalent health problems.

Key words: sleep disruption; cellular ultrastructure; gene expression; metabolism; mood; insomnia

\section{Significance Statement}

Disruption of the duration, timing, and continuity of sleep affects cellular ultrastructure, gene expression, appetite regulation, hormone production, vigilance, and reward functions.

\section{Introduction}

Many insights into why sleep is a highly conserved biological phenomenon can be gleaned from observing the consequences of its disruption due to experimental manipulations or as a result of natural causes such as aging or disease. Given the propensity for modern life to disrupt sleep, whether through behavioral sleep curtailment or sleep fragmentation, and given the mounting epidemiological evidence linking sleep disturbances and disease, a better understanding of the mechanisms underlying the

Received July 8, 2015; revised Aug. 17, 2015; accepted Aug. $27,2015$.

This work was supported by the Netherlands Organization of Scientific Research (NWO Grant VICI-453.07.001) and the European Research Council (Advanced Grant 671084) to E.V.S., the National Institutes of Health (Grants R01MH099231 and P01NS083514 to C.C.; Grants P01 AG-11412 R01-0H009482 to the National Institute for Occupational Safety and Health and E.V.C.), the Biotechnology and Biological Sciences Research Council (Grant BB/ F022883) and the Royal Society (Wolfson Research Merit Award) to D.J.D., the National Medical Research Council Singapore (STaR Investigatorship Award to M.C.W.L.), the Swiss National Science Foundation (Grant 320030135653), and the National Center of Competence in Research in Affective Sciences financed by Swiss National Science Foundation Grant 51NF40-104897 to S.S.

Correspondence should be addressed to Eus J.W. Van Someren, Department of Sleep and Cognition, Netherlands Institute for Neuroscience, Meibergdreef 47, 1105 BA, Amsterdam, The Netherlands. E-mail: e.van.someren@nin.knaw.nl.

DOI:10.1523/JNEUROSCI.2592-15.2015

Copyright $\odot 2015$ the authors $\quad 0270-6474 / 15 / 3513889-07 \$ 15.00 / 0$ detrimental effects of sleep disruption is clearly needed. In search for answers to fundamental questions on the "essential" (Cirelli and Tononi, 2008), cellular (Cirelli, 2009), multiple (Van Someren, 2010), or nonspecific (Siegel, 2012) functions of sleep, an unabatedly growing number of studies have applied the common methodology of interfering with sleep and observing the consequences. Deprivation can be applied continuously, intermittently, or in a stage-dependent way to either completely or partially deprive organisms of sleep. Consequences differ depending on the modality of experimental sleep disruption. Many studies in the past have described the consequences of acute sleep loss, but the focus has recently been expanded to include chronic sleep disruption, a more common condition in everyday life. Although superficially more subtle than total sleep deprivation (TSD), chronic sleep disruption has far-reaching consequences that will be summarized in the present mini-review, starting from the effects on brain cells and ending with recent insights in the mechanisms involved in the chronically disrupted sleep experienced by people suffering from insomnia, one of the most prevalent disorders. In some cases, negative consequences result from the fragmentation of the normal sleep pattern into short sleep bouts frequently interrupted by brief awakenings, even if the total 
daily amount of sleep is not decreased. The relevance of findings from experimental studies is supported by observational studies on the consequences of naturally occurring sleep disruption, whether due to environmental and societal demands or pathological conditions such as sleep-disordered breathing or insomnia. The resulting insights lay ground for a mechanistic understanding of the epidemiological finding that disrupted sleep contributes to the major health challenges facing our aging society, including type 2 diabetes, cardiovascular disease, neurodegeneration, and depression.

\section{Effect of disrupted sleep on the ultrastructure of brain cells} One approach to understanding the consequences of chronic sleep restriction is to look at how it affects the brain at the cellular level. For instance, in a recent study, mice were subjected to chronic sleep fragmentation for 14 weeks to mimic the frequent awakenings experienced by patients with sleep apnea. Chronic sleep disruption led to mitochondrial stress, neuronal degeneration, and cell loss in specific groups of neurons important to maintain arousal, including the orexinergic neurons in the hypothalamus and the noradrenergic neurons of the locus ceruleus in the pons (Zhu et al., 2015). Even a month after the end of the experiment, mice were less able to stay awake at night when they are normally more active, suggesting that damage to arousalpromoting cells may be long-lasting (Zhu et al., 2015). Other experiments focused on adolescent mice because of a long-held concern that young brains are more sensitive to the negative effects of sleep loss, even though there is little direct evidence to support this view (Astill et al., 2012; Owens et al., 2014). Recent experiments used electron microscopy to gain insight into the mechanisms by which sleep loss affects brain cells, and specifically pyramidal neurons in the frontal cortex (L. de Vivo, A.B. Nelson, M. Bellesi, J. Noguti, G. Tononi, C. Cirelli, unpublished data). In the cell bodies of these glutamatergic cells, which represent $\sim 80 \%$ of all cortical neurons, the analysis focused on mitochondria and several components of the endocytotic pathway, from early endosomes to lysosomes. These organelles carry out basic cellular functions ranging from energy production and nutrient intake to membrane turnover and prevention of metabolic and oxidative stress. Adolescent mice were studied under four conditions: ad libitum sleep, TSD of $6-8 \mathrm{~h}$, chronic sleep restriction to $1 / 3$ of their habitual sleep for $\sim 4 \mathrm{~d}$, or recovery sleep for $\sim 2 \mathrm{~d}$ after $4 \mathrm{~d}$ of chronic sleep restriction. It was found that there are many quantitative ultrastructural differences in the adolescent mouse cortex that reflect, not only behavioral state (sleep vs wake), but also "quality" of sleep (baseline sleep vs recovery sleep after sleep loss) and duration of wake (acute sleep loss vs chronic sleep restriction). In fact, using a combination of 11 ultrastructural parameters, it was possible to assign individual pyramidal neurons to the correct experimental group with an accuracy of $\sim 70 \%$. Some of the ultrastructural changes, such as signs of mitochondrial activation, were already present after short sleep deprivation and became more pronounced with chronic sleep restriction. Other parameters, such as signs of lysosomal activation, were only present after prolonged sleep disruption, suggesting that chronic sleep loss imposes a greater burden to brain cells than acute sleep loss. For all of these parameters, the betweenmice variance tended to increase after acute and chronic sleep loss relative to sleep. This trend toward higher interindividual variability may reflect true biological heterogeneity unmasked by sleep loss, which is consistent with human studies showing that there are stable, trait-like differences in the susceptibility to cog- nitive impairment caused by sleep loss (Van Dongen et al., 2004; Rupp et al., 2012).

\section{A time to sleep}

Both the amount of sleep and its timing with respect to the internal circadian clock are important. In recent years, the extent and direction of this interrelatedness has been investigated at the behavioral and molecular levels. The circadian phase at which we sleep influences many aspects of sleep. Sleep duration and continuity, the amount of REM sleep, and sleep spindle activity are all modulated by the circadian phase at which we sleep; for example, night or day (Dijk and Czeisler, 1995). Slow waves, putative markers of synaptic strength (Tononi and Cirelli, 2014), have long been thought to be regulated by the duration and intensity of wakefulness and subsequent sleep (Borbély and Achermann, 1999). Some characteristics of slow waves, such as their slope and amplitude, which vary along the anterior-posterior brain axis, are affected by the circadian phase at which we sleep (Lazar et al., 2015). The effects of circadian phase on sleep structure also imply that it matters when you sleep because REM sleep, sleep spindles, and slow waves have all been implicated in functions of sleep such as memory consolidation (for review, see Rasch and Born, 2013). In addition to the timing of sleep, accumulating evidence suggests that there is also a minimum requirement of continuous unperturbed sleep to ensure optimal sleep-supported memory processes (van der Werf et al., 2009; Djonlagic et al., 2012; Varga et al., 2014).

\section{Effect of insufficient or mistimed sleep on rhythmic gene expression}

Circadian rhythms are generated by a set of core clock genes and this molecular machinery is present in the suprachiasmatic nucleus (SCN), but also in cells throughout the body (Partch et al., 2014). This machinery drives circadian rhythmicity in an organand tissue-specific manner. Forty-three percent of all proteincoding genes show circadian rhythms in transcription (Zhang et al., 2014). Recent animal and human data provide strong evidence that the timing of sleep and sleep deprivation can have a profound influence on this rhythmicity in the peripheral transcriptome (for a recent review, see Archer and Oster, 2015). In mice, sleep deprivation can lead to an $80 \%$ reduction in rhythmic transcripts in the brain (Maret et al., 2007). When sleep occurs at night, when temperature is low and melatonin is high, $\sim 6.4 \%$ of the human blood transcriptome is rhythmic. When sleep is delayed by $4 \mathrm{~h}$ every day, the percentage of genes that are transcribed rhythmically is reduced to $1 \%$ for an overall $84 \%$ reduction (Archer et al., 2014). Furthermore, 1 week of insufficient sleep reduces rhythmicity of the blood transcriptome transcriptome by 20\% (Möller-Levet et al., 2013). Therefore, sleep timing and sleep debt can influence circadian rhythmicity in the periphery (outside of the SCN). Short or mistimed sleep disrupts the rhythmic expression of core clock genes associated with chromatin modification, transcription, and translation, as well as genes implicated in inflammatory, immune, and stress responses. These alterations could be mechanisms that account for why short and mistimed sleep affects health.

\section{Effect of disrupted sleep on hormones and metabolism}

Landmark studies conducted in rats in the late eighties and early nineties demonstrated that extended periods of near TSD produced a reliable syndrome including debilitated appearance, impaired immune function, increased food intake, increased energy expenditure, weight loss, impaired temperature regulation, ele- 
vated norepinephrine levels, decreased plasma thyroxine, and eventual death (Rechtschaffen et al., 1989; Everson, 1993; Rechtschaffen and Bergmann, 2002). These studies provided unequivocal evidence that the "function" of sleep extends beyond the brain. Examination of hormonal and metabolic consequences of sleep loss and sleep disruption in these rodent models was largely limited to assays in single blood samples. Whether the main finding from the rat model that sleep deprivation has major adverse effects on health could be extrapolated to conditions of sleep loss in human remained very much in doubt. During the following two decades, sleep disturbances, including insufficient sleep, poor sleep quality, insomnia, obstructive sleep apnea, and mistimed sleep (as occurs in shift workers) became endemic chronic conditions in humans living in industrialized societies. These trends for shorter and poorer sleep developed over the same time period as the dramatic increase in the prevalence of obesity and diabetes. Evidence has accumulated to indicate that sleep loss has important negative health consequences. Prospective epidemiological studies in both children and adults suggest a causative role of short sleep in the increased risk of weight gain. Sleep curtailment is associated with dysregulated neuroendocrine control of appetite that includes a reduction of the satiety factor leptin, an increase in the hunger-promoting hormone ghrelin, and an increase in daytime levels of endocannabinoids (Reutrakul and Van Cauter, 2014). Sleep loss may alter the ability of leptin and ghrelin to signal caloric need accurately, producing an internal misperception of insufficient energy availability that could promote hedonic feeding. The increased hunger induced by sleep restriction leads to increased energy intake, particularly in the form of snacking (Nedeltcheva and Scheer, 2014). Recent studies using whole-room indirect calorimetry have shown that sleep restriction increases energy need, but only modestly (Markwald et al., 2013). In comparison, the increased appetite reported by sleep-deprived subjects and their increased energy intake in the presence of ad libitum feeding appear to exceed the energy demands of extended wakefulness under sedentary conditions. Sleep disturbances, including experimental sleep fragmentation (Tasali et al., 2008; Stamatakis and Punjabi, 2010), insomnia with short sleep duration, sleep apnea, and mistimed sleep, have been linked to abnormal glucose metabolism and increased diabetes and cardiovascular risk. Several large prospective studies suggest that these sleep disturbances are associated with an increased risk of incident diabetes. Obstructive sleep apnea, which combines sleep fragmentation and hypoxemia, is a major risk factor for insulin resistance and possibly diabetes. Whether glycemic control in type 2 diabetes patients can be improved by treating sleep apnea remains controversial. In addition, evidence from animal models and experimental studies in humans have identified disruption of the circadian system as a novel putative risk factor for adverse metabolic outcomes. Short or fragmented sleep decreases insulin sensitivity and increases the risk of type 2 diabetes and obesity due to a decrease in energy expenditure, a dysregulation of the hormonal control of hunger, excessive snacking, and an increased hedonic drive for food intake. The current evidence strongly suggests that these sleep and circadian disturbances may be involved in the epidemic of obesity and type 2 diabetes.

\section{Disrupted sleep affects reward networks in the brain}

Although sleep disturbances have adverse neuroendocrine and metabolic effects (see previous section), it is also well known that chronic sleep disruption and sleep deprivation may be associated with severe cognitive performance deficits (see next section). However, impairments in stress coping and emotional regulation often prevail. For example, when healthy human participants engage in risky choices, a night of TSD can heighten the response of brain areas sensitive to reward while dulling responses in areas sensitive to losses (Venkatraman et al., 2011), with major consequences on decision making. How can we explain these deleterious effects of sleep disruption? Neuroimaging, neurophysiological, and clinical studies suggest that emotional and reward networks are activated during sleep. Such activation may promote the reprocessing of emotional or rewarded information during sleep and dreaming and optimize affective regulation and behavioral responses during wakefulness (Perogamvros and Schwartz, 2012, 2054). Supporting this hypothesis, studies in rodents reported that neuronal firing patterns recorded during a reward-searching behavior spontaneously reemerge across hippocampal and reward circuits during subsequent periods of slowwave sleep. This offline replay is orchestrated by hippocampal ripples and was proposed to strengthen the association between a memory trace and its motivational value (Lansink et al., 2009; Singer and Frank, 2009). In humans, too, the consolidation of motivationally relevant information seems to benefit from oscillatory activity predominating during sleep (sleep spindles and slow-waves) (Wilhelm et al., 2011; Oudiette et al., 2013) and may implicate the activation of the dopamine system during sleep (Feld et al., 2014). By impeding these neural mechanisms, sleep curtailment alters the integration and regulation of reward-based learning and decision making.

In a recent study, K. Igloi, G. Gaggioni, V. Sterpenich, and S. Schwartz (unpublished data) demonstrated that postlearning sleep favors the selectivity of long-term consolidation by retaining the most important (i.e., rewarded) memories. These effects were mediated by an increased functional interplay between the dopaminergic reward regions, the prefrontal cortex and hippocampus. The data further showed that sleep spindles strengthened memory representations based on reward values, suggesting a privileged replay of information yielding positive outcomes. These findings demonstrate that postlearning sleep determines the neural fate of motivationally relevant memories and promotes a value-based stratification of long-term memory stores.

An important, unanswered question is whether reward influences the types of neural patterns replayed during sleep in humans. V. Sterpenich, H.D. Yang, M. van Schie, M. Catsiyannis, A. Ramyead, S. Perrig, D. Van De Ville, and S. Schwartz (unpublished data) used simultaneous EEG-fMRI and neural decoding methods (Horikawa et al., 2013) and showed that spatiotemporal patterns of brain activity associated with an experience that led to a successful outcome (winning a game) had a higher probability of reemerging during slow-wave sleep. Collectively, these new data indicate that sleep disruption has deleterious consequences on a healthy emotional balance by hindering a form of neural reverberation that predominates during sleep and helps our brains learn from our daily failures and accomplishments.

\section{Predicting individual differences in cognitive performance after sleep loss}

Sustained attention is a cognitive domain that is robustly affected by sleep loss (Lim and Dinges, 2010; Lo et al., 2012). Degraded neurobehavioral performance shows marked trait-like individual differences (Van Dongen et al., 2004; Rupp et al., 2012), so identifying persons who are more susceptible to vigilance decline without having to expose them to sleep loss could be useful in reducing the negative consequences of sleep restriction (e.g., accidents).

Drift diffusion modeling (DDM) of psychomotor vigilance test response times collected after a night of habitual sleep can 
predict the rate of behavioral lapsing induced by a night of TSD (Patanaik et al., 2014). DDM models perceptual decision-making by assuming that the brain extracts evidence for the presence of a stimulus at a constant rate over time (drift) that is perturbed by noise (diffusion) (Ratcliff and Van Dongen, 2011). This accumulation stops once enough evidence has been gathered to reach a decision. Vulnerable participants have a slower drift rate, but this is masked by their slightly faster nondrift contribution to response time. Therefore, greater vulnerability is not apparent from merely observing response times. DDM has been shown to predict TSD-induced vigilance decline with data collected at different times of day and the method has reproducibility across different samples (Patanaik et al., 2015).

\section{Autonomic and fMRI markers for individual differences in sensitivity to sleep loss}

Three other physiological predictors of vulnerability to vigilance decline after TSD have been identified. Heart rate variability (HRV) is an indicator of autonomic function that reflects the balance between time-varying parasympathetic and sympathetic influences on heart rate. HRV at the low-frequency band (0.02$0.08 \mathrm{~Hz}$ ) closely tracks the time course of the rate of behavioral lapsing over a $24 \mathrm{~h}$ period of sustained wakefulness (Chua et al., 2014a). Persons more vulnerable to vigilance decline after TSD have a slower resting heart rate and a higher HRV relative to those who are less vulnerable (Chua et al., 2014b), which could reflect higher vagal tone in such individuals. Because HRV is also lower in individuals reporting a greater frequency and duration of daily worry, it is possible that persons more resistant to vigilance decline after TSD tolerate high homeostatic sleep pressure because of hyperarousal.

With task-based fMRI, behavioral decline across several attention-demanding tasks is reliably correlated with the attenuation of task-related frontoparietal activation after TSD. This suggests that brain areas mediating attention control go offline to a greater extent when vulnerable persons are sleep deprived (Chee, 2014). Critically, activation appears to be more attenuated at all levels of task difficulty after TSD in these individuals, even with correct trials. Such individuals may thus have lower redundancy of neural activation when in a well-rested state and, as a result, become less well able to buffer the effects of local sleep when sleep deprived.

These findings might lead one to expect that greater task activation in the well-rested state will predict less vulnerability. However, the notion that less vulnerable persons have greater cognitive reserve as reflected by higher task activation appears to hold only for experiments involving working memory (Caldwell et al., 2005; Mu et al., 2005; Chee et al., 2006). Why state-related shifts in activation are a more reliable marker of vulnerability remains to be determined.

A limitation of task-related fMRI is that inferences are restricted to the areas recruited during task performance. In contrast, at least in theory, task-free (or resting-state) fMRI can assess the functional integrity of multiple brain regions and networks with minimal participant engagement. Sleep-deprived persons show functional connectivity changes resembling those observed during light sleep (Sämann et al., 2011), consistent with the occurrence of microsleeps and slow wave activity intrusions. Two sets of network changes characterize the altered functional connectivity that accompanies TSD: (1) reduced within-network connectivity in functionally related cortical regions and (2) reduced segregation of normally functionally segregated (or antagonistic) cortical networks (Sämann et al., 2010; De Havas et al.,
2012). Reduced functional connectivity of anticorrelated networks in the rested state appears to be useful for predicting vulnerability to vigilance decline after TSD, although these predictive regions differ slightly from those affected by sleep deprivation (Yeo et al., 2015).

\section{Individual differences in experiencing curtailed and disrupted sleep}

Much of the work discussed above concerns the responses to experimentally induced sleep disruption. However, in the absence of any perturbation originating in the environment, sleep can also be disrupted spontaneously. Individual differences occur, not only in the sensitivity to sleep loss, but also in the probability to experience such endogenously curtailed or fragmented sleep. Recent population-based studies suggest that these individual differences are not without consequences for brain function. In particular, people who have fragmented sleep-rather than people with short sleep duration-have increased risks of cerebral small vessel disease and mortality (Zuurbier et al., 2015a; Zuurbier et al., 2015b), as well as of poor cognitive and emotional functioning (Luik et al., 2015a; Luik et al., 2015b). The risks may in part be counteracted by interventions to promote adequate sleep-wake rhythms, especially at advanced age, when the endogenous circadian regulation of sleep weakens (Swaab et al., 1996; Van Someren and Riemersma, 2007).

However, behavioral genetics studies suggest that endogenous sleep problems may not be completely reversible. Heritability estimates of sleep variables range from $20-40 \%$ for habitual sleep duration to $>90 \%$ for sleep EEG-derived parameters (Landolt, 2008). The strength of genetic predispositions is underwritten by the surprising finding of a twin study demonstrating that, despite night-to-night variability, one's subjective evaluation of problems encountered during a single night is in part genetically determined (Boomsma et al., 2008). Molecular genetics studies have started to elucidate the genes involved. Polymorphisms in genes encoding clock and GABA receptor proteins have been proposed to provide the genetic underpinnings of the heritability of chronic insomnia, the most common of all endogenous sleep problems (for review, see Palagini et al., 2014).

For a number of reasons, it is relevant to the present review to examine chronic insomnia in some more detail. First, despite its name, insomnia is not so much a matter of sleep deprivation as it is fragmentation and variability in timing of sleep that appeared so relevant in the topics reviewed above (Vallières et al., 2005; Van Someren, 2007; Buysse et al., 2010; Feige et al., 2013). Second, insomnia is not only the most prevalent sleep disorder, but also the second-most prevalent mental disorder (Wittchen et al., 2011), and, because of its high prevalence, the associated societal costs are extremely high (Gustavsson et al., 2011). Third, insomnia contributes significantly to the risk or severity of cardiovascular, metabolic, mood, and neurodegenerative disorders (for review, see Bassetti et al., 2015). Fourth, a closer look at insomnia will illustrate the complexity of disentangling causes versus consequences of disturbed sleep, as well as their endogenous versus exogenous components.

In addition to the genes encoding for proteins with key roles in the sleep-regulatory mechanisms mentioned above, the heritability of insomnia has been proposed to involve a polymorphism in the gene encoding the 5HTTLPR serotonin transporter (Harvey et al., 2014). Carriers of the s/s allele are more likely to experience disturbed sleep in response to a stressful experience. It is important to note that this predisposition to "endogenous" insomnia involves a pathway that does not primarily serve a sleep- 
regulating role and is not specific to insomnia; it is also implicated in individual differences in stress responses, depression, anxiety, and posttraumatic stress disorder. Even though insomnia is commonly associated with these conditions, not all people suffering from insomnia are anxious or depressed.

We considered that the neural correlates of insomnia occurring comorbidly with depression or anxiety are not necessarily the same as the neural correlates of insomnia in those without affective symptoms. Preliminary findings of a voxel-based morphometry MRI study within a group of depressed patients suggest that those with a low density of gray matter in the thalamic pulvinar suffer the most severe insomnia (Van Someren et al., 2014). The association was specific to depressive patients and not present in healthy controls or in two patient control groups. Conversely, MRI scans in volunteers who were rigorously screened to exclude those with even slightly elevated symptoms of depression or anxiety pinpointed no involvement of the pulvinar, but rather a role for white matter integrity in individual differences in the strength of spindles and slow oscillations (Piantoni et al., 2013) and a role of orbitofrontal cortical (OFC) gray matter density in the severity of complaints about early morning awakening and insomnia (Altena et al., 2010; Stoffers et al., 2012). Supported by psychometric findings (Raymann and Van Someren, 2008; Diaz et al., 2013), these findings suggest that individuals with a low hedonic capacity are more likely to experience disrupted sleep, possibly because of a reduction in OFC output signaling contentment, a prerequisite for the brain to disengage from environmental monitoring and action preparation, reduce cortical excitability, and give in safely to the unconscious state of sleep (van der Werf et al., 2010; Stoffers et al., 2014).

Two major conclusions can be derived from these examples. First, disrupted sleep does not necessarily involve only primarily sleep regulatory circuits. Second, disrupted sleep is best regarded as a final common path of which the neural correlates differ depending on nonsleep phenotypes such as depression. Multivariate phenotyping appears essential to disentangle the different circuits that can be involved in insomnia (Van Someren et al., 2014).

\section{Discussion and perspective}

The presented findings show how research on the consequences of sleep disruption has matured over the last decades. The topics addressed in this mini-review are not exhaustive, not in the least because novel insights in adverse effects of keep emerging. A notable recent example concerns a possible role of disrupted sleep in neurodegeneration. Using real-time two-photon imaging in mice brains, Xie et al. (2013) showed a sleep-related increase in the interstitial space that markedly facilitated convection of interstitial and CSF, which could enhance removal of possibly neurotoxic waste including beta-amyloid. We expect the next decade to bring a wealth of highly relevant neuroscientific and clinical findings on this newly discovered role of sleep.

An emerging consensus from the findings reviewed here is that fragmented sleep may be at least as detrimental as curtailed sleep. Therefore, an outstanding question to be addressed in the next decade is why equal amounts of continuous versus interrupted sleep have such different outcomes. The wealth of studies on the favorable effects of sleep for brain function during the last decade may have led us to presume that any sleep, even fragmented, is better than no sleep. However, it might be that some processes that occur during sleep are so slow or require so many steps that premature interference results in unfinished states that adversely affect brain function. The possibility that sleep can also have adverse effects is already suggested by the amazing improvement of mood in some severely depressed people if they are deprived from their fragmented, incoherent sleep; at the same time, disturbed sleep may render individuals more vulnerable to stress and precipitate depressive episodes. Adverse effects may also occur with mistimed sleep. For example, a recent rodent model of posttraumatic stress disorder suggested that fear extinction is impaired if REM sleep occurs while the locus ceruleus is still activated by the recent fearful experience (Vanderheyden et al., 2014).

Another major question pertains to similarities and differences across the spectrum of a single acute sleep disruption to repeated disruption or even lifetime disruption. What happens on the trajectory from acute to chronic sleep disruption? Are compensatory/rescue mechanisms activated? What are the processes underlying adaptation and why do some processes fail to adapt? Equivocal results have been reported from studies that sought to determine whether allostatic adaptation to restricted sleep occurs (Kim et al., 2007; Leemburg et al., 2010; Van Someren, 2010; Deurveilher et al., 2015). If allostatic adaptation can truly be accomplished, how does it build up, what are the underlying mechanisms, and where are its limits?

In summary, it is clear that sleep disruption interferes profoundly with normal function, from the subcellular level to complex behavior, and with strong impacts on health and well-being.

\section{References}

Altena E, Vrenken H, van der Werf YD, van den Heuvel OAV, Van Someren EJ (2010) Reduced orbitofrontal and parietal grey matter in chronic insomnia: a voxel-based morphometric study. Biol Psychiatry 67:182-185. CrossRef Medline

Archer SN, Oster H (2015) How sleep and wakefulness influence circadian rhythmicity: effects of insufficient and mistimed sleep on the animal and human transcriptome. J Sleep Res. In press.

Archer SN, Laing EE, Möller-Levet CS, van der Veen DR, Bucca G, Lazar AS, Santhi N, Slak A, Kabiljo R, von Schantz M, Smith CP, Dijk DJ (2014) Mistimed sleep disrupts circadian regulation of the human transcriptome. Proc Natl Acad Sci U S A 111:E682-E691. CrossRef Medline

Astill RG, Van der Heijden KB, Van IJzendoorn MH, Van Someren EJ (2012) Sleep, cognition and behavioral problems in school-aged children: A century of research meta-analyzed. Psychol Bull 138:1109-1138. CrossRef Medline

Bassetti C, Ferini Strambi L, Brown S, Adamantidis A, Benedetti F, Bruni O, Cajochen C, Dolenc-Groselj L, Ferri R, Gais S, Huber R, Khatami R, Lammers GJ, Luppi PH, Peigneux P, Pollmächer T, Randerath W, Riemann D, Santamaria J, Schindler K, Tafti M, Van Someren EJ, Wetter TC (2015) Neurology and psychiatry: waking up to opportunities of sleep. Eur J Neurol. In press. CrossRef Medline

Boomsma DI, van Someren EJ, Beem AL, de Geus EJ, Willemsen G (2008) Sleep during a regular week night: a twin-sibling study. Twin Res Hum Genet 11:538-545. CrossRef Medline

Borbély AA, Achermann P (1999) Sleep homeostasis and models of sleep regulation. J Biol Rhythms 14:557-568. Medline

Buysse DJ, Cheng Y, Germain A, Moul DE, Franzen PL, Fletcher M, Monk TH (2010) Night-to-night sleep variability in older adults with and without chronic insomnia. Sleep Med 11:56-64. CrossRef Medline

Caldwell JA, Mu Q, Smith JK, Mishory A, Caldwell JL, Peters G, Brown DL, George MS (2005) Are individual differences in fatigue vulnerability related to baseline differences in cortical activation? Behav Neurosci 119: 694-707. CrossRef Medline

Chee MW (2014) Limitations on visual information processing in the sleepdeprived brain and their underlying mechanisms. Curr Opin Behav Sci 1:56-63.

Chee MW, Chuah LY, Venkatraman V, Chan WY, Philip P, Dinges DF (2006) Functional imaging of working memory following normal sleep and after 24 and 35 hours of sleep deprivation: Correlations of frontoparietal activation with performance. Neuroimage 31:419-428. CrossRef Medline

Chua EC, Yeo SC, Lee IT, Tan LC, Lau P, Tan SS, Ho Mien I, Gooley JJ 
(2014a) Individual differences in physiologic measures are stable across repeated exposures to total sleep deprivation. Physol Rep 2:e12129. CrossRef Medline

Chua EC, Yeo SC, Lee IT, Tan LC, Lau P, Cai S, Zhang X, Puvanendran K, Gooley JJ (2014b) Sustained attention performance during sleep deprivation associates with instability in behavior and physiologic measures at baseline. Sleep 37:27-39. Medline

Cirelli C (2009) The genetic and molecular regulation of sleep: from fruit flies to humans. Nat Rev Neurosci 10:549-560. CrossRef Medline

Cirelli C, Tononi G (2008) Is sleep essential? PLoS Biol 6:e216. CrossRef Medline

De Havas JA, Parimal S, Soon CS, Chee MW (2012) Sleep deprivation reduces default mode network connectivity and anti-correlation during rest and task performance. Neuroimage 59:1745-1751. CrossRef Medline

Deurveilher S, Bush JE, Rusak B, Eskes GA, Semba K (2015) Psychomotor vigilance task performance during and following chronic sleep restriction in rats. Sleep 38:515-528. Medline

Diaz BA, Van Der Sluis S, Moens S, Benjamins JS, Migliorati F, Stoffers D, Den Braber A, Poil SS, Hardstone R, Van't Ent D, Boomsma DI, De Geus E, Mansvelder HD, Van Someren EJ, Linkenkaer-Hansen K (2013) The Amsterdam Resting-State Questionnaire reveals multiple phenotypes of resting-state cognition. Front Hum Neurosci 7:446. Medline

Dijk DJ, Czeisler CA (1995) Contribution of the circadian pacemaker and the sleep homeostat to sleep propensity, sleep structure, electroencephalographic slow waves, and sleep spindle activity in humans. J Neurosci 15:3526-3538. Medline

Djonlagic I, Saboisky J, Carusona A, Stickgold R, Malhotra A (2012) Increased sleep fragmentation leads to impaired off-line consolidation of motor memories in humans. PLoS One 7:e34106. CrossRef Medline

Everson CA (1993) Sustained sleep deprivation impairs host defense. Am J Physiol 265:R1148-R1154. Medline

Feige B, Baglioni C, Spiegelhalder K, Hirscher V, Nissen C, Riemann D (2013) The microstructure of sleep in primary insomnia: an overview and extension. Int J Psychophysiol 89:171-180. CrossRef Medline

Feld GB, Besedovsky L, Kaida K, Münte TF, Born J (2014) Dopamine D2like receptor activation wipes out preferential consolidation of high over low reward memories during human sleep. J Cogn Neurosci 26:23102320. CrossRef Medline

Gustavsson A, Svensson M, Jacobi F, Allgulander C, Alonso J, Beghi E, Dodel R, Ekman M, Faravelli C, Fratiglioni L, Gannon B, Jones DH, Jennum P, Jordanova A, Jönsson L, Karampampa K, Knapp M, Kobelt G, Kurth T, Lieb R, et al; CDBE2010 Study Group (2011) Cost of disorders of the brain in Europe 2010. Eur Neuropsychopharmacol 21:718-779. CrossRef Medline

Harvey CJ, Gehrman P, Espie CA (2014) Who is predisposed to insomnia: a review of familial aggregation, stress-reactivity, personality and coping style. Sleep Med Rev 18:237-247. CrossRef Medline

Horikawa T, Tamaki M, Miyawaki Y, Kamitani Y (2013) Neural decoding of visual imagery during sleep. Science 340:639-642. CrossRef Medline

Kim Y, Laposky AD, Bergmann BM, Turek FW (2007) Repeated sleep restriction in rats leads to homeostatic and allostatic responses during recovery sleep. Proc Natl Acad Sci U S A 104:10697-10702. CrossRef Medline

Landolt HP (2008) Genotype-dependent differences in sleep, vigilance, and response to stimulants. Curr Pharm Des 14:3396-3407. CrossRef Medline

Lansink CS, Goltstein PM, Lankelma JV, McNaughton BL, Pennartz CM (2009) Hippocampus leads ventral striatum in replay of place-reward information. PLoS Biol 7:e1000173. CrossRef Medline

Lazar AS, Lazar ZI, Dijk DJ (2015) Circadian regulation of slow waves in human sleep: topographical aspects. Neuroimage 116:123-134. CrossRef Medline

Leemburg S, Vyazovskiy VV, Olcese U, Bassetti CL, Tononi G, Cirelli C (2010) Sleep homeostasis in the rat is preserved during chronic sleep restriction. Proc Natl Acad Sci U S A 107:15939-15944. CrossRef Medline

Lim J, Dinges DF (2010) A meta-analysis of the impact of short-term sleep deprivation on cognitive variables. Psychol Bull 136:375-389. CrossRef Medline

Lo JC, Groeger JA, Santhi N, Arbon EL, Lazar AS, Hasan S, von Schantz M, Archer SN, Dijk DJ (2012) Effects of partial and acute total sleep deprivation on performance across cognitive domains, individuals and circadian phase. PLoS One 7:e45987. CrossRef Medline

Luik AI, Zuurbier LA, Hofman A, Van Someren EJ, Ikram MA, Tiemeier H (2015a) Associations of the 24-hour activity rhythm and sleep with cognition: A population-based study of middle-aged and elderly persons. Sleep Med 16:850-855. CrossRef Medline

Luik AI, Zuurbier LA, Direk N, Hofman A, Van Someren EJ, Tiemeier H (2015b) 24-hour activity rhythm and sleep disturbances in depression and anxiety: a population-based study of middle-aged and older persons. Depress Anxiety. In press.

Maret S, Dorsaz S, Gurcel L, Pradervand S, Petit B, Pfister C, Hagenbuchle O, O'Hara BF, Franken P, Tafti M (2007) Homerla is a core brain molecular correlate of sleep loss. Proc Natl Acad Sci U S A 104:20090-20095. CrossRef Medline

Markwald RR, Melanson EL, Smith MR, Higgins J, Perreault L, Eckel RH, Wright KP Jr (2013) Impact of insufficient sleep on total daily energy expenditure, food intake, and weight gain. Proc Natl Acad Sci U S A 110: 5695-5700. CrossRef Medline

Möller-Levet CS, Archer SN, Bucca G, Laing EE, Slak A, Kabiljo R, Lo JC, Santhi N, von Schantz M, Smith CP, Dijk DJ (2013) Effects of insufficient sleep on circadian rhythmicity and expression amplitude of the human blood transcriptome. Proc Natl Acad Sci U S A 110:E1132-E1141. CrossRef Medline

Mu Q, Nahas Z, Johnson KA, Yamanaka K, Mishory A, Koola J, Hill S, Horner MD, Bohning DE, George MS (2005) Decreased cortical response to verbal working memory following sleep deprivation. Sleep 28:55-67. Medline

Nedeltcheva AV, Scheer FA (2014) Metabolic effects of sleep disruption, links to obesity and diabetes. Curr Opin Endocrinol Diabetes Obes 21: 293-298. CrossRef Medline

Oudiette D, Antony JW, Creery JD, Paller KA (2013) The role of memory reactivation during wakefulness and sleep in determining which memories endure. J Neurosci 33:6672-6678. CrossRef Medline

Owens J; Adolescent Sleep Working Group; Committee on Adolescence (2014) Insufficient sleep in adolescents and young adults: an update on causes and consequences. Pediatrics 134:e921-e932. CrossRef Medline

Palagini L, Biber K, Riemann D (2014) The genetics of insomnia-evidence for epigenetic mechanisms? Sleep Med Rev 18:225-235. CrossRef Medline

Partch CL, Green CB, Takahashi JS (2014) Molecular architecture of the mammalian circadian clock. Trends Cell Biol 24:90-99. CrossRef Medline

Patanaik A, Zagorodnov V, Kwoh CK, Chee MW (2014) Predicting vulnerability to sleep deprivation using diffusion model parameters. J Sleep Res 23:576-584. CrossRef Medline

Patanaik A, Kwoh CK, Chua EC, Gooley JJ, Chee MW (2015) Classifying vulnerability to sleep deprivation using baseline measures of psychomotor vigilance. Sleep 38:723-734. Medline

Perogamvros L, Schwartz S (2012) The roles of the reward system in sleep and dreaming. Neurosci Biobehav Rev 36:1934-1951. CrossRef Medline

Perogamvros L, Schwartz S (2015) Sleep and emotional functions. Curr Top Behav Neurosci 25:411-431. Medline

Piantoni G, Poil SS, Linkenkaer-Hansen K, Verweij IM, Ramautar JR, Van Someren EJ, van der Werf YD (2013) Individual differences in white matter diffusion affect sleep oscillations. J Neurosci 33:227-233. CrossRef Medline

Rasch B, Born J (2013) About sleep's role in memory. Physiol Rev 93:681766. CrossRef Medline

Ratcliff R, Van Dongen HP (2011) Diffusion model for one-choice reaction-time tasks and the cognitive effects of sleep deprivation. Proc Natl Acad Sci U S A 108:11285-11290. CrossRef Medline

Raymann RJ, Van Someren EJ (2008) Diminished capability to recognize the optimal temperature for sleep initiation may contribute to poor sleep in elderly people. Sleep 31:1301-1309. Medline

Rechtschaffen A, Bergmann BM (2002) Sleep deprivation in the rat: an update of the 1989 paper. Sleep 25:18-24. Medline

Rechtschaffen A, Bergmann BM, Everson CA, Kushida CA, Gilliland MA (1989) Sleep deprivation in the rat: X. Integration and discussion of the findings. Sleep 12:68-87. Medline

Reutrakul S, Van Cauter E (2014) Interactions between sleep, circadian function, and glucose metabolism: implications for risk and severity of diabetes. Ann NY Acad Sci 1311:151-173. CrossRef Medline

Rupp TL, Wesensten NJ, Balkin TJ (2012) Trait-like vulnerability to total and partial sleep loss. Sleep 35:1163-1172. Medline

Sämann PG, Tully C, Spoormaker VI, Wetter TC, Holsboer F, Wehrle R, Czisch M (2010) Increased sleep pressure reduces resting state functional connectivity. MAGMA 23:375-389. CrossRef Medline 
Sämann PG, Wehrle R, Hoehn D, Spoormaker VI, Peters H, Tully C, Holsboer F, Czisch M (2011) Development of the brain's default mode network from wakefulness to slow wave sleep. Cereb Cortex 21:2082-2093. CrossRef Medline

Siegel JM (2012) Evolution: suppression of sleep for mating. Science 337: 1610-1611. CrossRef Medline

Singer AC, Frank LM (2009) Rewarded outcomes enhance reactivation of experience in the hippocampus. Neuron 64:910-921. CrossRef Medline

Stamatakis KA, Punjabi NM (2010) Effects of sleep fragmentation on glucose metabolism in normal subjects. Chest 137:95-101. CrossRef Medline

Stoffers D, Moens S, Benjamins J, van Tol MJ, Penninx BW, Veltman DJ, Van der Wee NJA, Van Someren EJ (2012) Orbitofrontal gray matter relates to early morning awakening: a neural correlate of insomnia complaints? Front Neurol 3:105. Medline

Stoffers D, Altena E, van der Werf YD, Sanz-Arigita EJ, Voorn TA, Astill RG, Strijers RL, Waterman D, Van Someren EJ (2014) The caudate: a key node in the neuronal network imbalance of insomnia? Brain 137:610620. CrossRef Medline

Swaab DF, Van Someren EJ, Zhou JN, Hofman MA (1996) Biological rhythms in the human life cycle and their relationship to functional changes in the suprachiasmatic nucleus. Prog Brain Res 111:349-368. CrossRef Medline

Tasali E, Leproult R, Ehrmann DA, Van Cauter E (2008) Slow-wave sleep and the risk of type 2 diabetes in humans. Proc Natl Acad Sci U S A 105:1044-1049. CrossRef Medline

Tononi G, Cirelli C (2014) Sleep and the price of plasticity: from synaptic and cellular homeostasis to memory consolidation and integration. Neuron 81:12-34. CrossRef Medline

Vallières A, Ivers H, Bastien CH, Beaulieu-Bonneau S, Morin CM (2005) Variability and predictability in sleep patterns of chronic insomniacs. J Sleep Res 14:447-453. CrossRef Medline

van der Werf YD, Altena E, Schoonheim MM, Sanz-Arigita EJ, Vis JC, De Rijke W, Van Someren EJ (2009) Sleep benefits subsequent hippocampal functioning. Nat Neurosci 12:122-123. CrossRef Medline

van der Werf YD, Altena E, van Dijk KD, Strijers RL, De Rijke W, Stam CJ, van Someren EJ (2010) Is disturbed intracortical excitability a stable trait of chronic insomnia? A study using transcranial magnetic stimulation before and after multimodal sleep therapy. Biol Psychiatry 68:950-955. CrossRef Medline

Van Dongen HP, Baynard MD, Maislin G, Dinges DF (2004) Systematic interindividual differences in neurobehavioral impairment from sleep loss: evidence of trait-like differential vulnerability. Sleep 27:423-433. Medline

Van Someren EJ (2007) Improving actigraphic sleep estimates: how many nights? J Sleep Res 16:269-275. CrossRef Medline

Van Someren EJ (2010) Doing with less sleep remains a dream. Proc Natl Acad Sci U S A 107:16003-16004. CrossRef Medline
Van Someren EJ, Riemersma-Van Der Lek RF (2007) Live to the rhythm, slave to the rhythm. Sleep Med Rev 11:465-484. CrossRef Medline

Van Someren EJ, Benjamins J, Stoffers D, Hoekstra T, Migliorati F, Van Tol M-J, Twisk JWR (2014) Brain structure and large-scale psychometrics point to different subtypes of insomnia. Soc Neurosci Abstr 40:676.12

Vanderheyden WM, Poe GR, Liberzon I (2014) Trauma exposure and sleep: using a rodent model to understand sleep function in PTSD. Exp Brain Res 232:1575-1584. CrossRef Medline

Varga AW, Kishi A, Mantua J, Lim J, Koushyk V, Leibert DP, Osorio RS, Rapoport DM, Ayappa I (2014) Apnea-induced rapid eye movement sleep disruption impairs human spatial navigational memory. J Neurosci 34:14571-14577. CrossRef Medline

Venkatraman V, Huettel SA, Chuah LY, Payne JW, Chee MW (2011) Sleep deprivation biases the neural mechanisms underlying economic preferences. J Neurosci 31:3712-3718. CrossRef Medline

Wilhelm I, Diekelmann S, Molzow I, Ayoub A, Mölle M, Born J (2011) Sleep selectively enhances memory expected to be of future relevance. J Neurosci 31:1563-1569. CrossRef Medline

Wittchen HU, Jacobi F, Rehm J, Gustavsson A, Svensson M, Jönsson B, Olesen J, Allgulander C, Alonso J, Faravelli C, Fratiglioni L, Jennum P, Lieb R, Maercker A, van Os J, Preisig M, Salvador-Carulla L, Simon R, Steinhausen HC (2011) The size and burden of mental disorders and other disorders of the brain in Europe 2010. Eur Neuropsychopharmacol 21:655-679. CrossRef Medline

Xie L, Kang H, Xu Q, Chen MJ, Liao Y, Thiyagarajan M, O'Donnell J, Christensen DJ, Nicholson C, Iliff JJ, Takano T, Deane R, Nedergaard M (2013) Sleep drives metabolite clearance from the adult brain. Science 342:373-377. CrossRef Medline

Yeo BT, Tandi J, Chee MW (2015) Functional connectivity during rested wakefulness predicts vulnerability to sleep deprivation. Neuroimage 111: 147-158. CrossRef Medline

Zhang R, Lahens NF, Ballance HI, Hughes ME, Hogenesch JB (2014) A circadian gene expression atlas in mammals: implications for biology and medicine. Proc Natl Acad Sci U S A 111:16219-16224. CrossRef Medline

Zhu Y, Fenik P, Zhan G, Xin R, Veasey SC (2015) Degeneration in arousal neurons in chronic sleep disruption modeling sleep apnea. Front Neurol 6:109. Medline

Zuurbier LA, Luik AI, Hofman A, Franco OH, Van Someren EJ, Tiemeier H (2015a) Fragmentation and stability of circadian activity rhythms predict mortality: The Rotterdam Study. Am J Epidemiol 181:54-63. CrossRef Medline

Zuurbier LA, Ikram MA, Luik AI, Hofman A, Van Someren EJ, Vernooij MW, Tiemeier H (2015b) Cerebral small vessel disease is related to disturbed 24-hour activity rhythms: a population-based study. Eur J Neurol. In press. 